\title{
Cellular injury to 1- to 3+-year-old stems of Camellia sinensis by Tuckerella japonica
}

\author{
Diann S. Achor ${ }^{1} \cdot$ Carl C. Childers $^{2}$ (D) Michael E. Rogers ${ }^{3}$
}

Received: 28 July 2017/Accepted: 26 October 2017/Published online: 29 November 2017

(C) The Author(s) 2017. This article is an open access publication

\begin{abstract}
Tuckerella japonica Ehara (Acari: Tuckerellidae) feeds on predigested plant cells beneath exposed periderm tissue of 1- to 3+-year-old stems of Camellia sinensis (L.) O. Kuntze (Theaceae) where longitudinal bark splitting occurs. Control samples from these tissues were compared with areas fed upon by $T$. japonica adults and immatures to characterize types of cellular injury. Stylet diameters ranged from 1.6 to $2.3 \mu \mathrm{m}$ and were consistent with observed stylet punctures in the stems. Mite saliva was injected along tracts within the cortical tissue and resulted in cell wall disruption, collapsed cells and, in older tissue, hyperplasia. The range of potential stylet penetration into plant tissues was from 92 to $150 \mu \mathrm{m}$. Tuckerella japonica injects saliva in the cortical tissues. The paired stylet lengths would allow for possible injection of saliva into the upper areas of phloem tissue but not in the cambium area of wood exposed by splitting of the outer epidermis.
\end{abstract}

Keywords Tuckerellidae $\cdot$ Plant feeding injury by mites $\cdot$ Peacock mites $\cdot$ Tetranychoidea

Diann S. Achor is retired from University of Florida, Lake Alfred, FL, USA.

Carl C. Childers

ccc1957@ufl.edu

Diann S. Achor

WAchor@tampabay.rr.com

Michael E. Rogers

mrgrs@ufl.edu

1 University of Florida, Lake Alfred, FL, USA

2 Citrus Research and Education Center, University of Florida, Lake Alfred, FL, USA

3 Citrus Research and Education Center, University of Florida, 700 Experiment Station Road, Lake Alfred, FL 33850, USA 


\section{Introduction}

The Tetranychidae, Tenuipalpidae and Eriophyoidea comprise a large group of mite species that feed mainly on higher plants and numerous species are of economic importance (Banerjee and Cranham 1985; Childers and Derrick 2003; de Lillo and Skoracka 2010; Leigh 1985; McMurtry 1985). Some species of Tenuipalpidae and Eriophyidae are vectors of a number of viral diseases many of which cause significant economic losses to cultivated plants (Oldfield and Proeseler 1996; Childers and Derrick 2003; Rodrigues et al. 2016; Malagnini et al. 2016). Several eriophyoid mites are capable of producing galls or other abnormal growth on plants from their feeding (Westphal and Manson 1996; de Lillo and Monfreda 2004). A third group of eriophyoid mites can directly cause serious injury and damage to various plants from their feeding with the citrus rust mite, Phyllocoptruta oleivora (Ashmead), the pink citrus rust mite, Aculops pelekassi (Keifer), the grape rust mite, Calepitimerus vitis (Nalepa) and the apple rust mite, Aculus schlectendali (Nalepa) as examples (Childers 1994; Oldfield 1996; Khederi et al. 2014).

The Tetranychoidea and Eriophyoidea have piercing, paired stylets for their mouthparts but their morphology as well as feeding mechanisms and injuries differ (de Lillo et al. 2002). The citrus rust mite has shorter stylets (about $30 \mu \mathrm{m}$ ) with feeding injury confined to the epidermis of citrus fruit or leaves (Albrigo and McCoy 1974; McCoy and Albrigo 1975; Achor et al. 1990). Citrus rust mite feeding injury on citrus leaves and fruit resulted in evacuated epidermal cells or cell injury that led to necrosis of cellular contents. In contrast, stylet lengths of Tetranychidae have been reported to be about $100 \mu \mathrm{m}$ in (Jeppson et al. 1975) and in an adult female of Panonychus ulmi (Koch), were recorded to be $118 \mu \mathrm{m}$ (Avery and Briggs 1968). Their longer stylets permit penetrating into the mesophyll of the leaf and cortical layers of the fruit. Injury by P. citri (McGregor) to citrus leaves or fruit consisted of evacuated cells, sometimes leaving starch grains, or collapsed cells that were totally evacuated (Albrigo et al. 1981). In one study, feeding resulted in the collapse of the phloem in vascular bundles near stylet paths of the six-spotted spider mite, Eotetranychus sexmaculatus (Riley). The collapse was speculated to be caused by the extent of stylet penetration and mite saliva to the nearby photosynthate producing cells supporting the phloem rather than direct feeding in the phloem tissue (Albrigo et al. 1981).

Recovery has been observed in both types of feeding injury to leaves and fruit. In the case of the deeper feeding injury to leaves or fruit by the citrus red mite, P. citri, mesophyll cells surrounding the injured cells divided (hyperplasia) and replaced the cells that had been evacuated or collapsed due to feeding (Albrigo et al. 1981). In rust mite feeding, wound periderm has been observed to form due to injury to the epidermis (Achor et al. 1990).

Brevipalpus californicus (Banks), B. phoenicis (Geijskes) and B. yothersi Baker have been shown to be vectors of one or more viruses in plants (Chagas et al. 2003; Kondo et al. 2003; Kitajima et al. 2003; Rodrigues et al. 2003, 2016). In many instances, virus lesions from these non-systemic diseases occurred on stems as well as leaves and fruit, thus indicating that these mites fed on stems too. The diversity within this species complex is only beginning to be recognized (Sanchez-Velazquez et al. 2015).

Tuckerella japonica has been observed feeding on exposed green periderm tissues in the crevasses created by splitting bark on 1- to 3+-year-old woody stems of tea [Camellia sinensis (L.) O. Kuntze] (Childers et al. 2016). With the descriptions of typical injury and recovery patterns caused by the above groups of mites in mind, this study was designed to examine the crevasses in which $T$. japonica was found to define the type of injuries to underlying tissues. The following steps were taken to describe these injuries: (1) examine 
the crevasse tissues with scanning electron microscopy (SEM) to document punctures caused by penetration of the paired stylets, (2) use light and SEM to determine the length and diameter of the stylets and compare these measurements with punctures, (3) examine and describe the control tissues from crevasse areas of stems of $C$. sinensis extending from the inner vascular cambium layer to the outer developing cork periderm layer, (4) characterize cellular injury by $T$. japonica to those tissues, (5) examine the stylet track areas with a definitive stain, safranin, to determine if feeding tracks were from lignification or saliva, and (6) determine by comparison of stylet lengths to depth of discernible injury, whether stylet penetration by $T$. japonica in $C$. sinensis stems extended into the vascular cambium as suggested by Charles (2009).

Studies that show the locations and types of cellular injury to a host plant by a Tuckerella species are lacking. This paper reports on the injury incurred within 2-year-old stems of $C$. sinensis by stylet penetration and injection of saliva by $T$. japonica. The sampled varieties were not available for release as they are considered proprietary by the owner.

\section{Materials and methods}

\section{Scanning electron microscopy (SEM) of mite feeding punctures}

All 1- to 3-year-old stems for this study were taken between 2014 and 2016 from the Charleston Tea Plantation on Wadmalaw Island in Charleston, SC, USA. Approximately 30 to $100 \mathrm{~cm}$ lengths of 2-year-old stems of $C$. sinensis between 0.5 and $1.0 \mathrm{~m}$ and with longitudinal splitting of the bark were cut in the field with pruning shears, returned to the laboratory in Charleston, SC and examined using a stereomicroscope. Twenty 2 to $3 \mathrm{~cm}$ lengths of these stems showing evidence of $T$. japonica resting or feeding were cut using pruning shears. A second series of twenty 2 to $3 \mathrm{~cm}$ lengths of the same stems with no evidence of mite presence were taken each time for comparison.

Each piece was subsequently cut down the middle of the stem with a razor blade so that the rounded area where the mite(s) were located was evident. Each piece was immediately transferred into one of two vials (mites either present or absent) containing 3\% glutaraldehyde in $0.1 \mathrm{M}$ Sorenson's buffer, $\mathrm{pH} 7.2$ and kept on ice in transit from Charleston until further processing $24 \mathrm{~h}$ later in the laboratory at the Citrus Research and Education Center (CREC) in Lake Alfred, FL, USA. There the samples were washed 3 times in Sorenson's buffer, post fixed in $2 \%$ osmium tetroxide in the same buffer and kept overnight at $4{ }^{\circ} \mathrm{C}$. The following morning the samples were rinsed again in buffer, dehydrated in ethanol (10\% steps, 10 min for each step) and dried using a Ladd Critical Point Dryer (Ladd Research Industries, Burlington, VT, USA). The dried samples were mounted on stubs, coated with gold/palladium using a Ladd Sputter Coater (Ladd Research Industries) studied and photographed with a Hitachi S530 Scanning Electron Microscope (Hitachi High-Technologies, Japan).

\section{Light microscopy (LM) and transmission electron microscopy (TEM) of plant tissues and mite injury from stylet penetration and injection of saliva}

Two to $3 \mathrm{~mm}$ squared pieces of the above samples were prepared for TEM by placing them in $3 \%$ glutaraldehyde fixative and further processing them in the laboratory. The samples were rinsed in buffer, post-fixed in osmium as above, and rinsed again in buffer before 
dehydration in acetone (10\% steps, 10 min for each step). Subsequently the samples were infiltrated in Spurr's resin (Spurr 1969) over a 3 day period, placed in molds and hardened in an oven at $70{ }^{\circ} \mathrm{C}$. One micrometer thick sections were prepared with a glass knife on a LKB Huxley Ultramicrotome (LKB Instruments, Sweden), stained with methylene blue/ azure A and counter stained with basic fuchsin (Humphrey and Pittman 1974) for light microscopy. Sections were observed under an Olympus BX61 compound microscope (Cambridge Scientific Products, Watertown, MA, USA) and photographed using an OMAX CMOS 14mp digital camera. Ultrathin sections for TEM were prepared with a diamond knife on the same ultramicrotome, stained with $2 \%$ aqueous uranyl acetate, poststained with Reynolds lead citrate (Reynolds 1963), and photographed using a Morgagni 268 transmission electron microscope (FEI Company, The Netherlands).

\section{Paraffin embedded samples for light microscopy (LM)}

Samples of 1- and 2-year-old stems with visible splitting of the bark, containing tuckerellid mites or free of mites were collected in the Charleston Tea Plantation and placed in moist bags and kept on ice. The samples were then transported to CREC and the following day they were processed for light microscopy. Areas of obvious bark splitting were excised from the stems using razor blades and placed in FAA fixative (Formalin-Alcohol-Acetic Acid) overnight at $4{ }^{\circ} \mathrm{C}$. The following day the samples were rinsed in $50 \%$ ethanol and dehydrated up to $100 \%$ ethanol (20\% steps, $1 \mathrm{~h}$ for each step). The tissue was then cleared by infiltration with tert-Butanol (TBA) in 3 steps: 100\% ethanol; TBA 3:1 1 h, 1:1 1 h, 1:3 $1 \mathrm{~h}$ to overnight at room temperature. The tissue was subsequently infiltrated with liquid paraffin at $60{ }^{\circ} \mathrm{C}$ as follows: 3:1 TBA:liquid paraffin $6 \mathrm{~h}$ to overnight, 1:1 TBA:liquid paraffin overnight, followed by 3 changes in liquid paraffin each overnight at $60{ }^{\circ} \mathrm{C}$. The samples were placed in molds, covered with liquid paraffin and placed in a refrigerator at $4{ }^{\circ} \mathrm{C}$ to solidify. Serial $10 \mu \mathrm{m}$ sections of stem samples were prepared using a Leica RM 2155 rotary microtome (Leica Microsystems, Germany). The sections were mounted in water on glass slides and cured at $30{ }^{\circ} \mathrm{C}$ on a warming tray. The slides were stained with safranin/fast green (Sass 1958). With this staining, lignin, chromatin, cutin and saliva stain red, chloroplasts stain pink to red; and cellulose walls and cytoplasm stain green.

Control tissues were punctured with a 000 insect pin $(0.25 \mathrm{~mm}$ diam $)$ to rule out results due to mere mechanical injury by feeding. They were prepared from stem pieces of 1- or 2-year growth as above. Three separate samplings were made: five samples punctured and processed for microscopy at the time of collection, 5 punctured then processed $48 \mathrm{~h}$ later, and 5 more processed 3 days after the stem pieces were punctured. These were all processed for paraffin embedding using the above method. Light micrographs were prepared using the Olympus BX61 compound microscope as described above.

\section{Measurements of Tuckerella japonica stylets with LM and SEM}

For LM measurements, the mites were collected and stored in $80 \%$ ethanol and slidemounted later in Hoyer's medium (Walter and Krantz 2009). Micrographs were taken using the Olympus BX61 compound microscope. The stylets were measured using Figi measurement software (Schindelin et al. 2012).

For SEM measurements, mites that were observed feeding were sprayed with chloroform to attempt to quickly kill them while the stylets were protracted and then transferred into $80 \%$ ethanol to preserve them. In the laboratory, the mites were dehydrated further through 3 changes of $100 \%$ ethanol then critical point dried as above. Each mite was then 
carefully mounted on a stub, sputter coated and observed as above. The stylet images were measured using Figi measurement software (Schindelin et al. 2012).

\section{Results and discussion}

Nine puncture measurements in the plant tissues ranged from 0.85 to $2.3 \mu \mathrm{m}$ in diameter (Table 1). Stylet punctures by motile stages of $T$. japonica are shown in Fig. 1 . The locations of these punctures were in green periderm tissues exposed by longitudinally split bark on 1- to 3+-year-old woody stems. As 1-year-old stems increased in size, there was increased longitudinal splitting of the periderm with 2-year-old stems having the most bark splitting (Bond 1942; Childers et al. 2016). Stylet lengths and diameters are presented in Table 1. Only 4 mites had stylet lengths greater than $70 \mu \mathrm{m}$ when chloroform was applied. Measurements of these stylets from SEM photos were: 76.1, 81.6, 100.2, and $110 \mu \mathrm{m}$ and partial retraction was believed to have occurred in each instance. The width of $T$. japonica stylets was consistent with the width of the SEM photos shown in Fig. 1. The entire stylets could be viewed through the transparent body of the mite with LM and these were the measurements for comparison.

Figure 2 shows cross sections of healthy bark from young (1 year woody stems) and older (2-3 year woody stems) extending from the inner vascular cambium layer ( $\mathrm{VCa}$ ) to the outer developing cork periderm layer (CP). Figure 2 a shows the edge of a crevasse with the outer cork layer and sloughed epidermal layer (Ep) creating a sheltered area in which $T$. japonica were frequently found (asterisks). In this young stem, the cork periderm is only 3 cell layers thick and overlays a cortical region (C) of 5-6 cell layers thick. Below the

Table 1 Measurements of one (single) or two (double) stylet diameter $(\mu \mathrm{m})$ of immature and mature Tuckerella japonica and puncture width $(\mu \mathrm{m})$ using scanning electron microscopy (SEM) and stylet section lengths $(\mu \mathrm{m})$ of slide-mounted mites using light microscopy (LM) and SEM images

\begin{tabular}{lll}
\hline Stylet width (SEM) & Immatures & Matures \\
\hline Single tip lateral & $0.5-0.6$ & $1.0-1.3$ \\
Single tip dorsal & $0.4-0.8$ & $1.3-1.7$ \\
Single lateral & $0.6-0.8$ & \\
Double lateral & 1.2 & 2.3 \\
Double dorsal/ventral & $0.7-1.3$ & 2.2 \\
\hline
\end{tabular}

Measurements of punctures (SEM)

\begin{tabular}{lll}
\hline Average & 0.98 & 1.9 \\
Range & $0.85-1.1$ & $1.6-2.3$ \\
$\mathrm{~N}$ & 5 & 4 \\
\hline
\end{tabular}

Stylet lengths (LM and SEM)

(A) From pharynx to tip of infracapitulum $(n=16)$

$42.7(39.3-46.8)$

From tip of infracapitulum to stylet tip $(n=16)$

$86.7(60-120)$

(B) Entire stylet outside of infracapitulum $(n=8)$

168.5 (135-193)

Working stylet $(=\mathrm{B}-\mathrm{A})$

92-150

Stylet length $(\mathrm{SEM})(\mathrm{n}=4)$

$76.1-110.7$ 
Fig. 1 Scanning electron micrographs of Tuckerella japonica stylet punctures (white arrows) on exposed periderm cells in fissures revealed by the splitting of the outer cork periderm layers
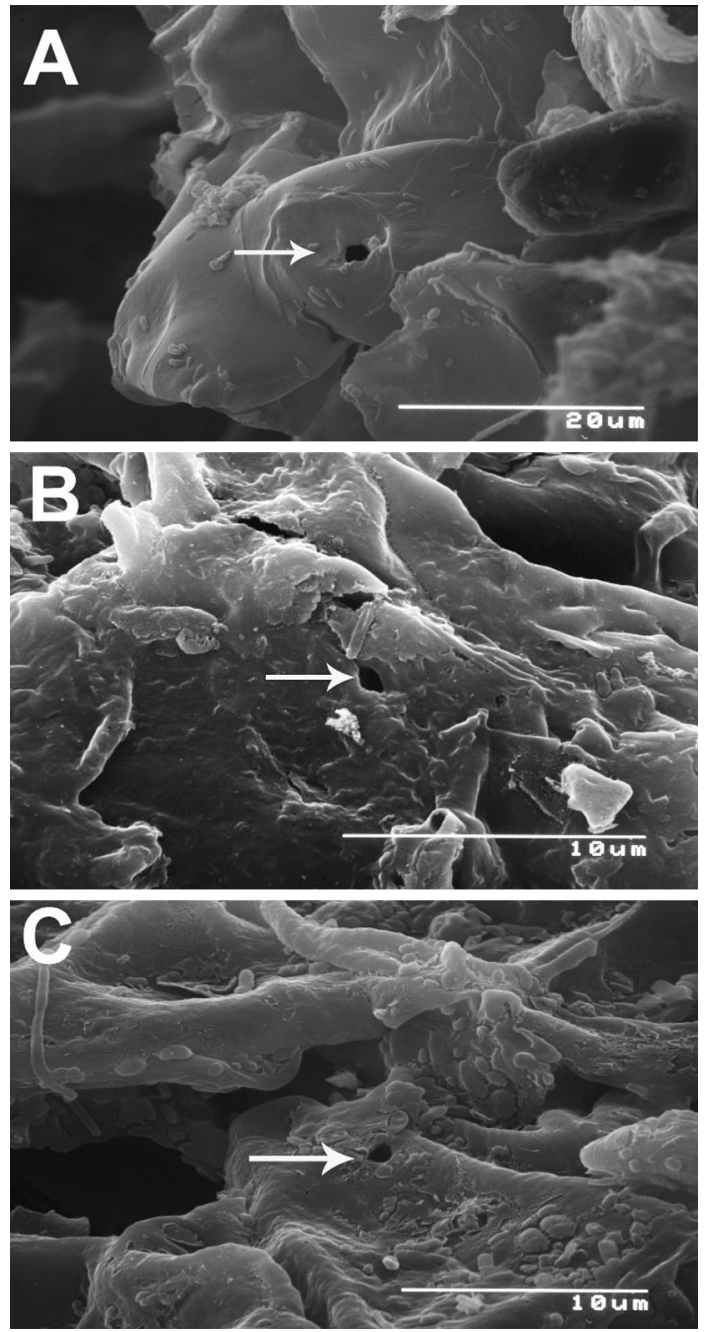

cortex is the area of active phloem (P) (Fig. 2b) consisting of thick walled sieve elements (SE), companion cells (CC) and phloem parenchyma (PP). Below the phloem layers is the vascular cambium (VCa) which, in this example, is 2-4 cells thick. Two points are to be noted: the orderliness of the arrangement of the cortical cells and the vascular rays (VR) and relative emptiness of the cortical cells and phloem parenchyma. The cells are not actually empty, the cytoplasm is simply pushed against the walls by a large central vacuole (asterisks) as shown by TEM in Fig. 3b, c. Because of this characteristic of the cortical cells and phloem parenchyma, finding evacuated cells caused by feeding injury was difficult with both LM and TEM. Figures $2 b$ and $3 a, b$ show the normal appearance of phloem sieve elements (SE) in these young stems.

Figure 2c, d show the normal arrangement of tissues in the bark of 2-3 year old stems. Note that the cork periderm and cortical layers look very much like the younger stems but with the exception of some thickening of the walls of the inner cortical cells (red asterisks) and the normal compression of the protophloem (PrP) sieve elements (the outer, original 

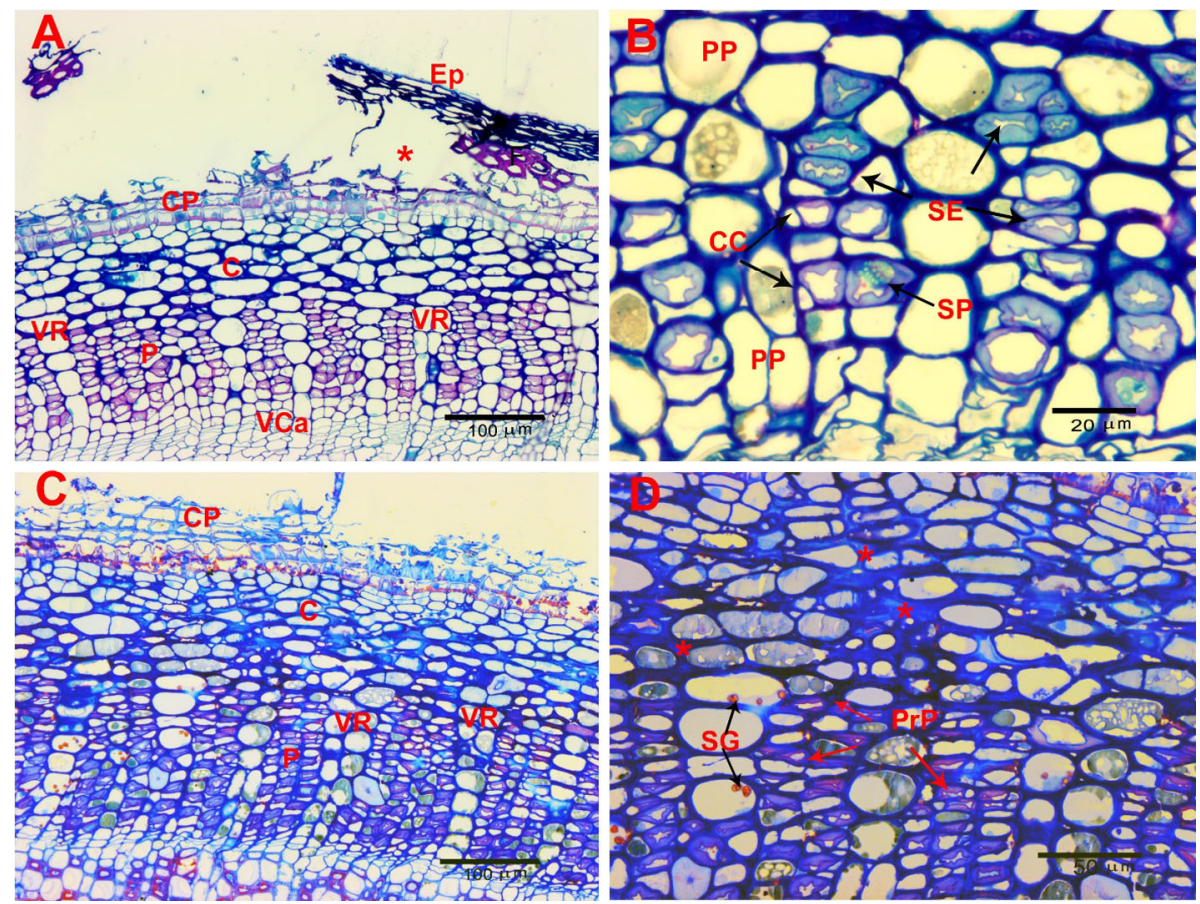

Fig. 2 Light micrographs taken at $1 \mu \mathrm{m}$ sections stained with methylene blue/azure A/basic fuchsin of control 1- and 2-year-old stems. a Cross section of part of 1-year-old stem under a fissure (asterisk). $E p$ epidermal layer, $C P$ cork periderm, $C$ cortex, $P$ phloem, $V R$ vascular ray, $V C a$ vascular cambium. b Higher magnification of 1-year-old-stem showing. $S E$ sieve elements, $P P$ phloem parenchyma, $C C$ companion cells. c Cross section of 2-year-old-stem in middle of fissure. Area labels as above. d Higher magnification of 2-year-old stem. $S G$ starch grains, $\operatorname{Pr} P$ collapsing protophloem sieve elements, red asterisks-areas of normal thickening of cortical primary cell walls

phloem elements laid down in the developing stem) caused by compression from the expansion of the active phloem layers (Fig. 3c). Note in Fig. 2c the persistent regularity of arrangement of the vascular rays (VR) and cortical cells.

LM sections were examined for evidence of punctures or stylet tracks of collapsed cell walls in the tissue. Figure $4 \mathrm{a}, \mathrm{b}$ (arrows) show some of the few areas of what appear to be disrupted cell walls caused by stylet punctures. In Fig. 4c, the arrows show what appears to be evidence of disruption of cells caused by a stylet-saliva path. The paraffin embedded tissue stained with Safranin and fast green (Fig. 4b, d, e) show conspicuously stained areas of what appear to be stylet-saliva tracks in the cortical layers. Safranin stains for the presence of lignin, suberin or saliva (Sass 1958). Specifically, safranin has been used to identify salivary tracks and sheaths produced by aphid and adelgid species (Pollard 1973; Young et al. 1995). In our case, we used it to distinguish between staining caused by salivary tracks and subsequent lignifications of affected tissues.

To determine whether the stylet tracks thus stained were from lignification or byproducts of saliva injection, we punctured live stems with a 000 -sized insect pin and looked for lignification. Figure $4 \mathrm{f}$ of a 3 day old puncture shows that our punctures did not result in the formation of lignin and suberin in the walls of the bordering disrupted cells. 
Fig. 3 Transmission electron micrographs of control phloem in 1-year-old-stems. a $S E$ sieve elements b Higher magnification of sieve elements showing thickened cell walls and lateral sieve plate filled with callose (C). c Lower magnification showing collapse of protophloem sieve elements. Asterisks in $\mathbf{a}, \mathbf{b}, \&$ c point to large central vacuoles of parenchyma cells
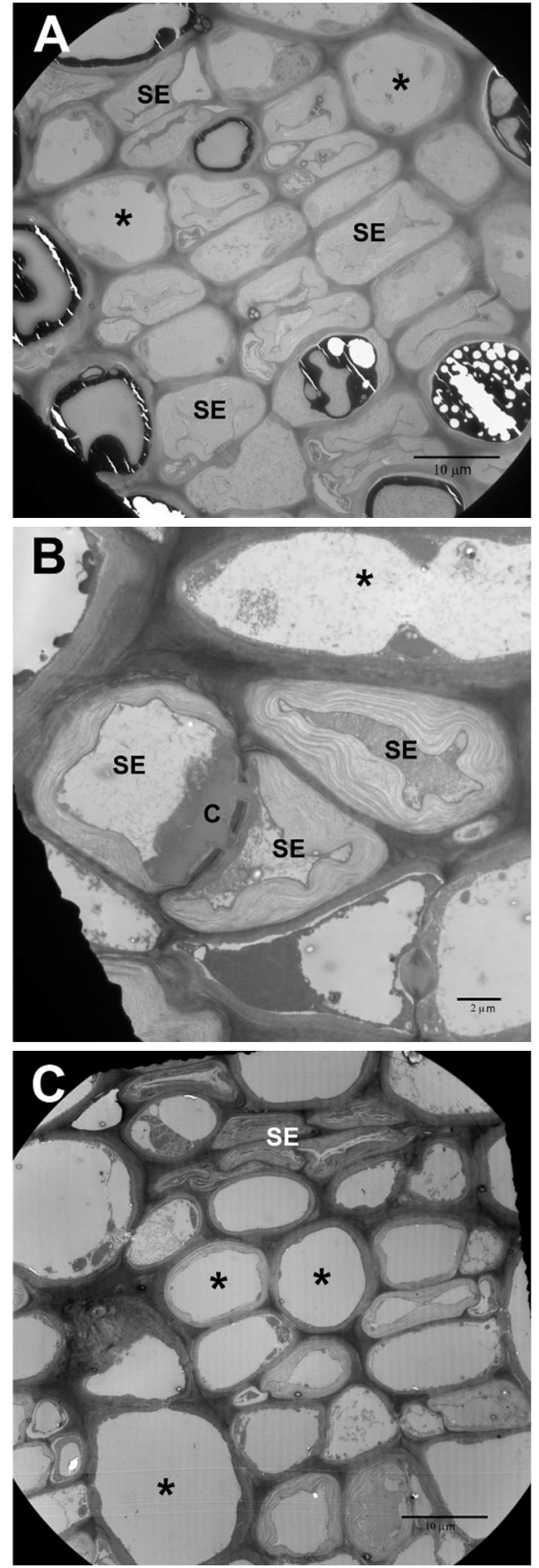

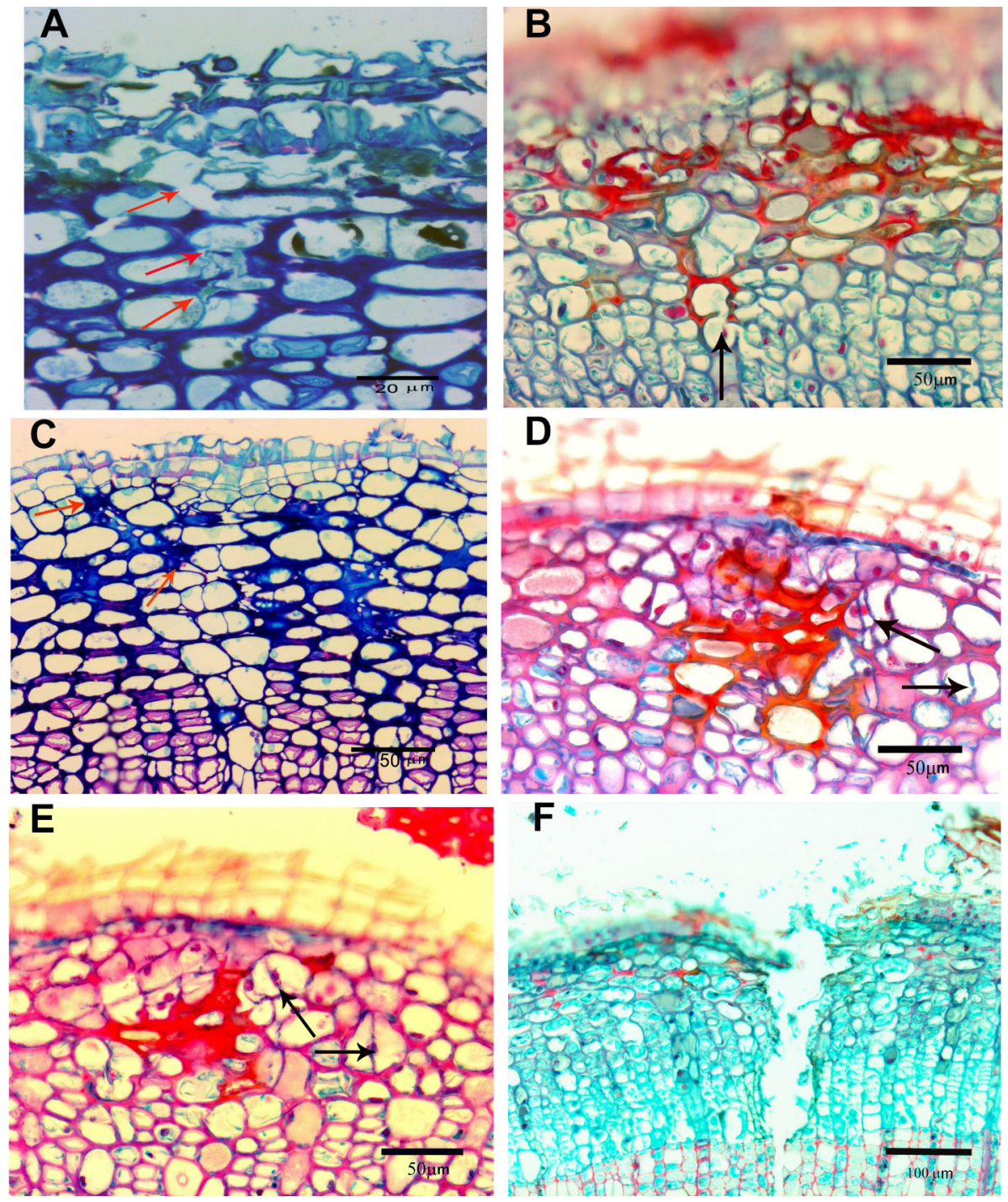

Fig. 4 Light micrographs of stylet probing injury in Camellia sinensis cortical tissues. a 1- $\mu$ m section with methylene blue/azure A/basic fuchsin. Arrow points to break in walls of cortical cells indicating passage of stylets. b $10-\mu \mathrm{m}$ section stained with safranin/fast green. Dark red staining indicates lignification or presence of mite-injected saliva. Arrow points to break in wall from paired stylet passage. $\mathbf{c} 1-\mu \mathrm{m}$ section stained as in a. Arrows point to possible path of stylets through cortical tissues. d, e 10- $\mu \mathrm{m}$ sections stained as in $\mathbf{b}$. Red stain indicates presence of mite saliva. Arrows point to new cell walls, indication of cell division (hyperplasia) occurring with recovery from cell injury. f $10-\mu \mathrm{m}$ section stained as in $\mathbf{b}$ of control puncture made with size 000 insect pin 3 days before sample was processed for microscopy injected along the stylet salivary tracks. Note lack of red staining in walls along the sides of the extensive puncture indicating lack of lignification from physical injury injected along the stylet salivary tracks 

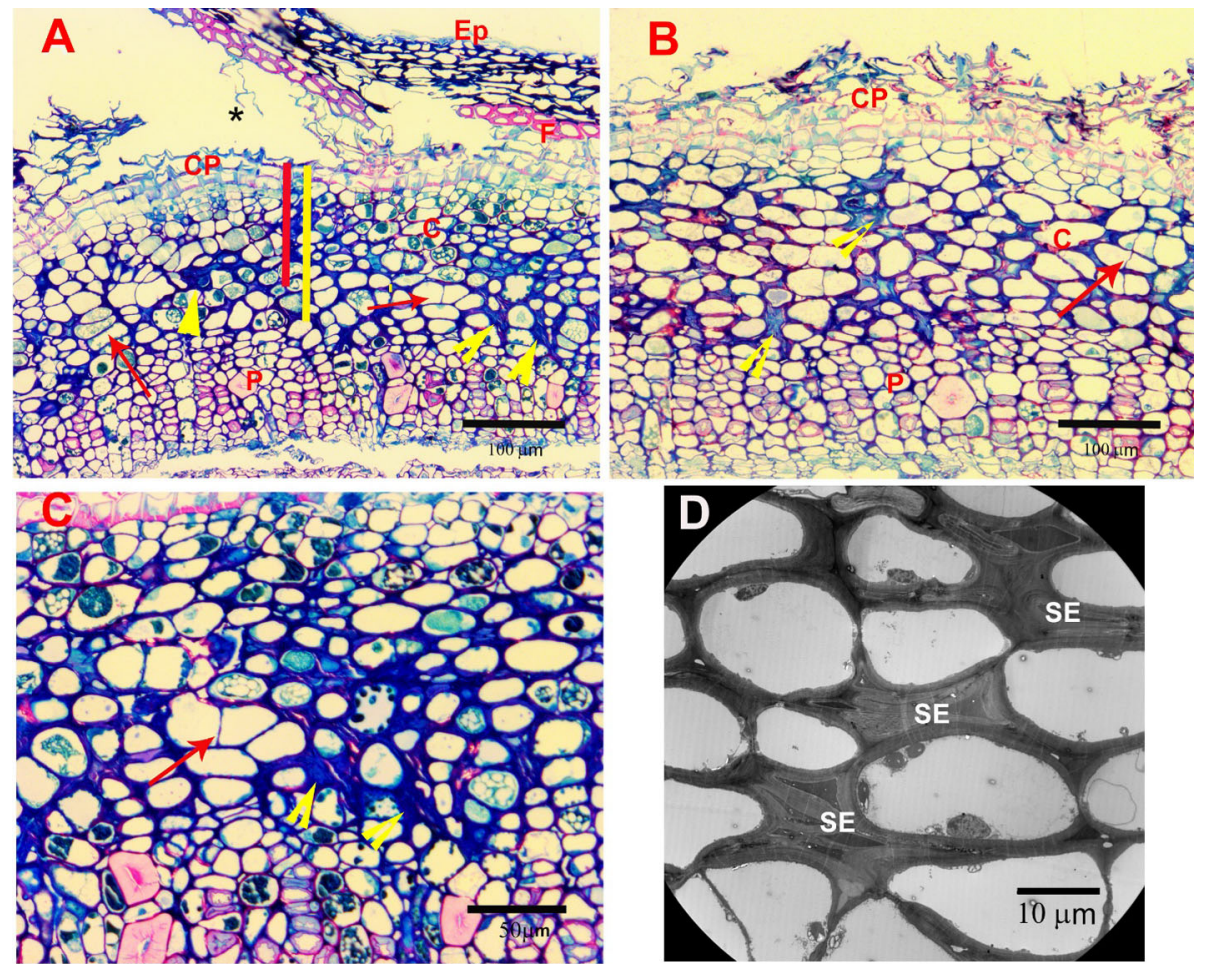

Fig. 5 Light and TEM micrographs of advanced injury to stem. a, b Light micrographs of stem showing extensive disorganization of the cortical cells caused by mite saliva, resulting in collapsed cells (yellow arrowheads) and hyperplasia (red arrows). Red and yellow bars show the minimum (red) and maximum (yellow) range of stylet extension into the cortical cells $(\mathrm{C})$. The maximum range extends into the outer layer of the phloem (P). CP cork periderm, Ep epidermal layer, $F$ fibers, *crevasse. c Higher magnifications of a. d TEM micrograph showing extensive collapse of sieve elements (SE) in outer layers of phloem

We concluded that the staining in the tissue was due to saliva proteins injected along the stylet feeding tracks.

Figure 4d, e (arrows) show evidence of newly divided cells (new cell walls) which is an indication of hyperplasia, an increase in the number of cells and a healing mechanism caused by wounded tissue. As previously mentioned, this is a common occurrence in spider mite damaged plant tissue. This type of recovery was also evident in the more severely affected tissue in Fig. 5a, b (red arrows).

Figure 5a-c show the disorganization caused by more extensive injection of saliva in a 2-year old stem. Salivary stylet tracts of collapsed cells are evident (yellow arrowheads). Figure $6 \mathrm{a}-\mathrm{d}$ are TEM images of those areas (asterisks) showing that they are collapsed cells rather than just thickened or lignified walls resulting from the aging of the tissue. Figure 6d shows two new sister cells from a cell division within a collapsed area of cells.

The question arose as to whether stylet penetration was confined to the cortical tissue or in the phloem or vascular cambium itself as suggested by Charles (2009). To help determine this, we measured the length of the stylets with both LM and SEM. We were unable to be certain that just measuring the stylet length that extended beyond the tip of the infracapitulum represented the full extent of its length. So we measured the entire stylet in 

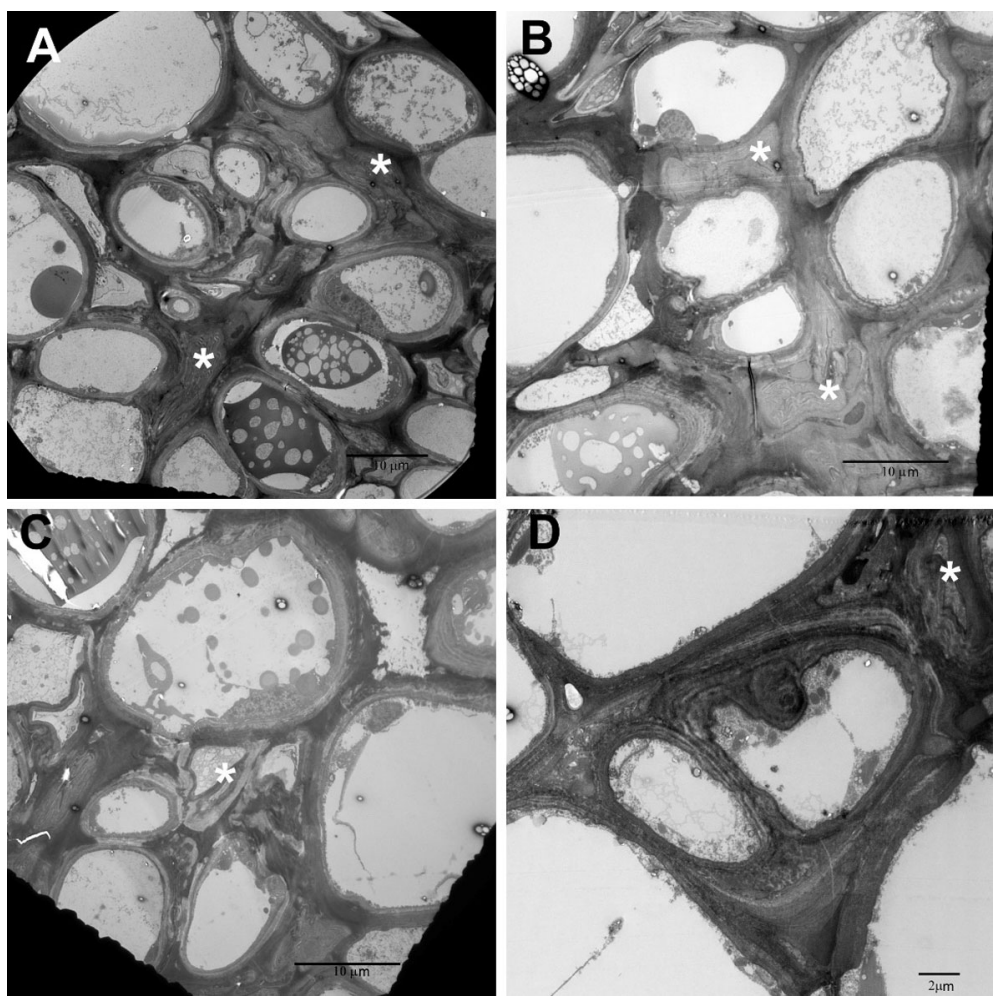

Fig. 6 a-c TEM micrographs of high magnifications of Fig. 5a-c showing the collapsed areas are actually collapsed cortical cells and collapsed sieve elements (white asterisks in $\mathbf{a}, \mathbf{b}$ ) rather than just thickening of cortical cell walls. d Two new sister cells (hyperplasia) occurring inside collapsed area

those mites in which the stylets were not confined by the infracapitulum and subtracted from it the measurements that were made of the distance from the base of the infracapitulum to its tip. We felt that this gave us the full potential length available for feeding. From this we determined that the range of potential stylet penetration was from 92 to $150 \mu \mathrm{m}$. The vertical lines in Fig. 5a show that the outer layers of phloem tissue would be available to the mites stylets but not the vascular cambium. Figure $5 \mathrm{~d}$ and $6 \mathrm{a}-\mathrm{c}$ (asterisks) show evidence of collapsed sieve elements found in young tissue (Fig. 3c), older tissue (Fig. 5d), and in advanced injury (Fig. 6b) (asterisks). Whether the mites actually penetrated these upper sieve elements or the cells merely collapsed due to injection of saliva into nearby tissues is undetermined.

The stylets of $T$. japonica were measured with a coverslip pressing on the flattened mite. The flattened mite has a strong internal fluid pressure that pushes out the stylophore and the other appendages (de Lillo, pers. comm.). de Lillo suspects that the working range of stylets could be shorter for these reasons. Future studies should include using pieces of coverslip placed in the mounting medium to minimize risk of flattening the mite specimens as well as use of other methods to determine stylet lengths. Tuckerellid species need to be assessed for their potential to access phloem tissues in their host plants that are of economic importance. 
Our conclusion is that $T$. japonica penetrates and injects saliva into the cortical tissue and possibly into the outer phloem tissue but not the vascular cambium in areas of bark exposed by splitting of the outer epidermis of 1- to 3+-year-old stems. Our evidence includes visible punctures, cellular collapse and cellular hyperplasia (wound healing) along obvious stylet-saliva tracks of the mites.

Acknowledgements Appreciation is extended to Dr. Enrico de Lillo Dipartimento di Scienze del Suolo, della Pienta e degli Alimenti, Univ. degli Studi "Aldo Moro" Amendola, Bari, Italy, and Dr. Beverly Gerdeman, Washington State University, NWREC, Mount Vernon and the external reviewers for their comments to improve this manuscript. We thank Holly Schugart for her suggestions in using paraffin embedding and staining.

Funding The funding was provided by University of Florida, CREC.

Open Access This article is distributed under the terms of the Creative Commons Attribution 4.0 International License (http://creativecommons.org/licenses/by/4.0/), which permits unrestricted use, distribution, and reproduction in any medium, provided you give appropriate credit to the original author(s) and the source, provide a link to the Creative Commons license, and indicate if changes were made.

\section{References}

Achor DS, Albrigo LG, McCoy CW (1990) Developmental anatomy of lesions on 'Sunburst' mandarin leaves initiated by citrus rust mite feeding. J Am Soc Hort Sci 116:663-668

Albrigo LG, McCoy CW (1974) Characteristic injury by citrus rust mite to orange leaves and fruit. Fla State Hort Soc 87:48-55

Albrigo LG, Childers CC, Syvertsen JP (1981) Structural damage to citrus leaves from spider mite feeding. Proc Int Soc Citric 2:649-652

Avery DJ, Briggs JB (1968) Damage to leaves caused by fruit tree red spider mite, Panonychus ulmi (Koch). J Hort Sci 43:463-473

Banerjee B, Cranham JE (1985) Tea, pp 371-374. In: Helle W, Sabelis MW (eds) Spider mites their biology, natural enemies and control. World crop pests 1B. Elsevier, Amsterdam

Bond TET (1942) Studies of the vegetative growth and anatomy of the tea plant (Camellia thea Link.) with special reference to the phloem. In: Blackman VH, Eames AJ, Oliver FW (eds) Annals Bot VI. Carendon Press, Oxford, pp 607-630

Chagas CM, Kitajima EW, Rodrigues JCV (2003) Coffee ringspot virus vectored by Brevipalpus phoenicis (Acari: Tenuipalpidae) in coffee. Exp Appl Acarol 30:203-313

Charles JG (2009) A preliminary review of the Tuckerellidae of the world. The New Zealand Institute for Plant \& Food Research Ltd, Auckland

Childers CC (1994) Biological control of phytophagous mites on Florida citrus utilizing predatory arthropods. In: Rosen D, Bennett FD, Capinera JL (eds) Pest management in the tropics. Biological controla Florida perspective. Intercept, Andover, pp 255-288

Childers CC, Derrick KS (2003) Brevipalpus mites as vectors of unassigned Rhabdoviruses in various crops. Exp Appl Acarol 30:1-231

Childers CC, Ebert TA, Rogers ME, Shepard M (2016) The occurrence and distribution of Tuckerella japonica (Acari: Tuckerellidae) on tea bushes, Camellia sinensis and C. assamica, in Alabama, Georgia, and South Carolina. Exp Appl Acarol 69:479-486

de Lillo E, Di Palma A, Nuzzaci G (2002) Morphological adaptations of mite chelicerae to different trophic activities (Acari). Entomologia 35(2001):125-180

de Lillo E, Monfreda R (2004) "Salivary secretions" of eriophyoids (Acari: Eriophyoidea): first results of an experimental model. Exp Appl Acarol 34:206-291

de Lillo E, Skoracka A (2010) What's "cool" on eriophyoid mites? Exp Appl Acarol 51:3-30

Humphrey CD, Pittman FE (1974) A simple methylene blue-azure A-basic fuchsin stain for epoxy-embedded tissue sections. Stain Tech 49:9-14

Jeppson LR, Keifer HH, Baker EW (1975) Mites injurious to economic plants. Univ Calif Press, Berkeley 
Khederi SJ, de Lillo E, Khanjani M, Gholami M (2014) Resistance of grapevine to the erineum strain of Colomerus vitis (Acari: Eriophyidae) in western Iran and its correlation with plant features. Exp Appl Acarol 63:15-35

Kitajima EW, Rezende JAM, Rodrigues JCV (2003) Passion fruit green spot virus vectored by Brevipalpus phoenicis (Acari: Tenuipalpidae) on passion fruit in Brazil. Exp Appl Acarol 30:225-231

Kondo H, Maeda T, Tamada T (2003) Orchid fleck virus: Brevipalpus californicus mite transmission, biological properties and genome structure. Exp Appl Acarol 30:215-223

Leigh TF (1985) Cotton. In: Helle W, Sabelis MW (eds) Spider mites their biology, natural enemies and control. World crop pests 1B. Elsevier, Amsterdam, pp 349-358

Malagnini V, de Lillo E, Saldarelli P, Beber R, Duso C, Raiola A, Zanotelli L, Valenzano D, Giampetruzzi A, Morelli M, Ratti C, Causin R, Gualandri G (2016) Transmission of grapevine Pinot gris virus by Colomerus vitis (Acari: Eriophyidae) to grapevine. Archiv Virol 161:2595-2599

McCoy CW, Albrigo LG (1975) Feeding injury to the orange caused by the citrus rust mite Phyllocoptruta oleivora (Prostigmata: Eriophyidae). Ann Entomol Soc Am 88:289-297

McMurtry JA (1985) Citrus. In: Helle W, Sabelis MW (eds) Spider mites their biology, natural enemies and control. World crop pests 1B. Elsevier, Amsterdam, pp 339-348

Oldfield GN (1996) Toxemias and other non-distortive feeding effects. In: Lindquist EE, Sabelis MW, Bruin J (eds) Eriophyoid mites-their biology, natural enemies and control. Elsevier, Amsterdam, pp 243-250

Oldfield GN, Proeseler G (1996) Eriophyoid mites as vectors of plant pathogens. In: Lindquist EE, Sabelis MW, Bruin J (eds) Eriophyoid mites - their biology, natural enemies and control. Elsevier, Amsterdam, pp 259-275

Pollard DG (1973) Plant penetration by feeding aphids (Hemiptera: Aphidoidea): a review. Bull Entomol Res 62:631-714

Reynolds ES (1963) The use of lead citrate at high $\mathrm{pH}$ as an electron-opaque stain for electron microscopy. J Cell Biol 17:208-212

Rodrigues JCV, Kitajima EW, Childers CC, Chagas CM (2003) Citrus leprosis virus vectored by Brevipalpus phoenicis (Acari: Tenuipalpidae) on citrus in Brazil. Exp Appl Acarol 30:161-179

Rodrigues JCV, Childers CC, Kitajima EW (2016) Brevipalpus spp (Acari: Tenuipalpidae) vectors of cytoplasmic and nuclear viruses in plants. In: Brown JK (ed) Vector-mediated transmission of plant pathogens. Amer Phytopathol Soc, St Paul, pp 309-318

Sanchez-Velazquez EJ, Santillan-Galicia MT, Novelli VM, Nunes MA, Mora-Aguilera G, Valez-Carrasco JM (2015) Diversity and genetic variation among Brevipalpus populations from Brazil and Mexico. PLoS ONE 10:e133861

Sass JE (1958) Botanical microtechnique. State College Press, New York

Schindelin J, Arganda-Carreras I, Frise E, Kaynig V, Longair M, Pietzsch T, Preibisch S, Rueden C, Saalfeld S, Schmid B, Tinevez JY (2012) Fiji: an open-source platform for biological-image analysis. Nat Methods 9(7):676-682

Spurr AR (1969) A low viscosity resin embedding medium for electron microscopy. J Ultrastruct Res 26:697-701

Walter DE, Krantz GW (2009) Collecting, rearing, and preparing specimens. In: Krantz GW, Walter DE (eds) A manual of acarology, 3rd edn. Texas Tech Univ Press, Lubbock, pp 83-96

Westphal E, Manson DCM (1996) Feeding effects on host plants: gall formation and other distortions. In: Lindquist EE, Sabelis MW, Bruin J (eds) Eriophyoid mites-their biology, natural enemies and control. Elsevier, Amsterdam, pp 231-242

Young RF, Shields KS, Berlyn GP (1995) Hemlock Woolly Adelgid (Homoptera: Adelgidae): stylet bundle insertion and feeding sites. Ann Entomol Soc Am 88:827-835 